\title{
A Case for International Financial Reporting Standard on Sustainability: A Critical Perspective
}

\author{
Vera Cherepanova ${ }^{1}$ \\ ${ }^{1}$ University College London, University of London, London, UK \\ Correspondence: Vera Cherepanova, University College London, University of London, London, UK. E-mail: \\ vera.cherepanova@gmail.com
}

Received: March 23, 2017

Accepted: April 27, 2017 Online Published: May 29, 2017

doi:10.5539/jms.v7n2p78

URL: http://doi.org/10.5539/jms.v7n2p78

\begin{abstract}
The domain of sustainability reporting has seen a substantial proliferation in recent years. Many standards, guidelines, and voluntary regulatory mechanisms have emerged, yet a specific IFRS on sustainability doesn't exist. This paper provides a critical analysis of desirability for the institutionalization of sustainability reporting in a form of IFRS standard. First, I discuss strengths and weaknesses of IFRS and their adoption. Next, I delineate the complex multi-dimensional nature of accounting harmonization and specifically highlight the existing barriers to the successful advancement of this process. I provide a justification why a complete convergence of national accounting standards is unlikely and even undesirable, given the diversity of cultures, enforcement mechanisms, tax and legal systems around the world. In the final section I review the concept of sustainability in its breadth and depth, and analyze how the usage of analogy to financial reporting may impose constraints on the scope of sustainability development goals. By contrast to financial reporting, sustainability reporting is addressed to a much wider group of stakeholders whose engagement is crucial for meaningful sustainable development goals. The paradigm of the IFRS does not render possible embracingthis wider scope, therefore, their applicability for the purposes of sustainability reporting is limited.
\end{abstract}

Keywords: IFRS, sustainability reporting, accounting harmonization, international accountability standards, global reporting initiative

\section{Introduction and Background}

Over the past decades, the world has witnessed a widespread diffusion of International Financial Reporting Standards (IFRS). Driven by further integration of capital markets, as well as by the overall trend of economic globalization, the process of international accounting harmonization gained active support of accounting bodies and business practitioners all over the world. Their concerted efforts have yielded positive results: today more than 120 countries permit or require IFRS for domestic listed companies (AICPA, 2017). However, the new form of global governance is required not only for financial reporting purposes. The domain of sustainability reporting has likewise seen a substantial proliferation in recent years. Many standards, guidelines, and voluntary regulatory mechanisms have emerged, yet a specific IFRS on sustainability doesn't exist.

The IFRS are developed by a supra-national body, the International Accounting Standards Board (IASB). IASB, a London-based independent organization, was established in 2001 as the successor of the International Accounting Standards Committee (IASC), whose rules issued between 1973 and 2001 are known as International Accounting Standards and are equally recognized by IASB.

A rapid pace of internationalization of accounting can be explained by the international economic integration between countries, accelerated cross-border capital investments and following growth of capital markets (Tweedie and Seidenstein, 2004). For the effective continued functioning of these markets, there is a need for a single set of high-quality international accounting standards (European Commission, 2009). Therefore, the purpose of IFRS is to support economic globalization, at the same time representing its natural outcome.

Indeed, the research studies provide evidence on benefits that IFRS adoption has brought to capital markets (Tarca, 2012): the reduced cost of capital (Li, 2010; Palea, 2007), increase in cross-border investments (DeFond et al., 2011; Yu, 2009), trading activity (Bruggemann et al., 2009), market liquidity (Daske et al., 2008) and volume of merger and acquisition (Francis et al., 2012). These results prove the claim that IFRS alleviate financial information asymmetries and therefore provide for a mitigated level of investment risks. The higher 
quality of information, more transparency, comparability, and disclosures lead to enhanced accuracy in forecasts (Horton, Serafeim, \& Serafeim, 2012; Phan, Mascitelli, \& Barut, 2013), reduce surprises in decisions and stimulate investment activity. Furthermore, as the disclosures become standardized, small investors are likely to find themselves in a better position with regards to investment professionals: the comprehensiveness and understandability of IFRS allow them to make equally informed trading decisions (Ball, 2006).

The adoption of IFRS produces cost savings for multinational corporations (MNCs) in terms of financial statements preparation by facilitating the consolidation process and eliminating many adjustments previously required for transformation from national GAAPs. The cost-cutting benefit is also applicable to the users of financial statements, such as investment analysts, creditors, regulatory bodies, rating agencies, and representatives of the general public since the time and effort needed to process financial information is reduced (Ball, 2006). Moreover, better-satisfied information needs of these stakeholders lead to enhanced corporate governance (Ball, 2006). From a standpoint of accounting regulatory bodies, a single set of accounting standards brings economies of scale: standard setting and development activities are concentrated around one set of standards instead of simultaneous scattered efforts of national accounting institutions in different countries. Auditors are able to standardize audit procedures and employee training programs, which potentially leads to a better quality assurance level (Tweedie \& Seidenstein, 2004).

However, this is only one side of the medal. Not all authors support the idea of adoption of international standards pointing out their disadvantages worth consideration.

Primarily, the conversion to IFRS is a substantial investment for a company. The transition costs, namely time, money and resources, come from switching from one system to another, employee recruitment and training, appropriate business processes reengineering. By the same token, this procedure represents a serious risk that some data might be lost or wrongly allocated when converting from the old system to the new one. Accordingly, the scale of conversion project in terms of risk and investment is big enough to dissuade a company from adopting IFRS.

Then, the adoption of IFRS raises a question of maintaining sovereignty over corporate regulation by national governments (Tarca, 2012; Whittington, 2008). In light of visibly dominating role of developed countries in the process of IFRS elaboration and dissemination, it is not surprising that some authors are quite radical and call it a "US hegemony over the world system" (Arnold, 2012) or "colonization of local cultures" (Lehman, 2005). Moreover, discontinuation of work on different national accounting systems means the absence of competition (Ball, 2006). The loss of better performance and improvements driven by competition, therefore, represent a potential opportunity cost of concentrating on a single accounting system.

Another widely discussed issue is the level of discretion provided by IFRS to companies. The IASB principles-based approach is being continually criticized for the lack of detail and substantial scope for subjective individual judgment, whereas, by contrast, the rules-based standards contain more explicit and specific guidance. Therefore, a significant level of discretion makes the quality of training, accounting skills and solid practical experience a prerequisite for the adequately applied judgment (Carmona \& Trombetta, 2008). As of today, there is no assurance that the level of accounting education is identically appropriate in different countries, which may cause inequable interpretations of the same reporting issues.

The discretion is "a double-edged sword" (Leuz, 2010): on one hand, it provides flexibility and allows to embrace the complexities of different companies and better reflect their economic realities, however, on the other hand, the managers who actually prepare financial statements may use it opportunistically for the manipulative purposes of misrepresentation of actual facts.

This leads to the question of the significance of incentives driving reporting practices (Tarca, 2012), surrounding institutional infrastructure (Leuz, 2010), effective steering and enforcement mechanisms. The high quality of a single set of accounting standards is important, however not sufficient alone for the realization of the listed benefits. Research studies consistently show that the achievement of comparability and following capital market advantages are feasible when firms are committed to transparency (Daske et al., 2011) and the levels of legal enforcement in the country are strict (Florou \& Pope, 2012; Beuselinck et al., 2009). Otherwise, the international standards may be unevenly implemented across countries, which would challenge their ability to reduce information asymmetry and level of investment risk (Ball, 2006).

Despite the existence of these and some other shortcomings of IFRS, the IASC, and later IASB has made a considerable progress in terms of accounting standards harmonization around the globe (Camfferman \& Zeff, 2006). The increscent adoption of IFRS by countries facilitated the reduction of differences in accounting. 
This study contributes to this literature by providing a critical analysis of desirability for the institutionalization of sustainability reporting in a form of IFRS standard. The following section discusses research methodology. Section three explores the complex multi-dimensional nature of accounting harmonization and specifically highlights the existing barriers to the successful advancement of this process. The final section discusses the concept of sustainability in its breadth and depth, and analyses how the usage of analogy to financial reporting may impose constraints on the scope of sustainability development goals.

\section{Analytical Approach and Methodology}

The research draws from the literature on international accounting harmonization including the works of Leuz (2010), Barlev \& Haddad (2007), Carmona \& Trombetta (2008), and Zeff (2007, 2012). The section of the paper dealing with sustainability reporting draws from the work of Mefford (2011), Voegtlin \& Scherer (2015), Scherer \& Palazzo (2011), Scherer, Palazzo, \& Seidl (2013). The classification of international accountability standards (IAS) proposed by Gilbert, Rasche, \& Waddock (2011) is used as a framework for the analysis of sustainability reporting initiatives.

The validity of the research is achieved by through the triangulation of multiple sources of evidence. While the study draws upon the references from relevant theories in the domains of accounting harmonization, sustainability and the IAS, it is triangulated to the primary source materials, including press releases, speeches, published reports and working papers, as well as other documents obtained from the relevant online archives. The research is supplemented by practical illustrations and examples.

\section{Literature Review: International Accounting Harmonization}

The term "accounting harmonization" can be defined as the process of reduction of differences in national accounting systems. The term was mainly used in times of IASC, whereas with the establishment of IASB the standard setters introduced the concept of convergence and started to use these two notions interchangeably (Zeff, 2007). The objective of both is to narrow down or eliminate differences between national accounting standards in order to increase the level of comparability of financial information. Barlev \& Haddad (2007) suggest that the definition of harmonization would vary as the level of expected comparability increases. Thus, a high level of comparability would mean "a complete harmonization".

In contrast with standardization, which implies the existence and validity of a uniform accounting system across the globe, harmonization has a distinguishing difference. The process of harmonization assumes capturing the best solutions from different standards and serving as the "highest possible denominator" of financial reporting (Tweedie \& Seidenstein, 2004). Presumably, this process raises the overall level of accounting standards across the world (Diaconu, 2007)

Regulatory bodies, accounting organizations, as well as representatives of international business, support the process of accounting harmonization headed by the locomotive of IASB. The reason for that is the anticipation of the long-awaited comparability of accounting information, representing the major benefit following from international harmonization. The qualitative characteristic of comparability is included into the framework of IASB and is particularly important from a standpoint of usefulness of financial statements (Wang, 2014). An increase in the level of comparability eliminates potential information externalities (Ball, 2006), makes "foreign" financial statements more reliable and compatible, which, in turn, facilitates cross-border transfers of information and capital stimulating global economic growth (Turner, 1983; Wang, 2014).

However, a number of studies have shown that international accounting harmonization doesn't bring the significant improvement of financial statements comparability (Goelrz, 1991; Taylor, 1987; Carlson, 1997). For this reason, as well as for the others discussed below, a number of authors express their concerns about achievability and overall desirability of harmonization (Leuz, 2010).

Although the harmonization process is a far more inclusive approach than a mere standardization, nevertheless, the major barrier to its success lies in differences in national cultures, legal, tax and enforcement systems. Even an appropriate interpretation to a different language can be a challenge. Differences in monitoring and enforcement mechanisms, which remain a responsibility of national regulators, impede the comparability of financial statements. These institutional characteristics represent a system of inter-dependent elements and vary between countries due to historical and geographical reasons (Leuz, 2010). Consequently, changing only one element, i.e., accounting standards, will not be sufficient for the achievement of genuine harmonization as long as all other elements remain unchanged. Arnold (2012) has shown in her analysis of anti-crisis measures taken by G-7 to respond to the East Asian financial crisis in the late 1990s that due to the lack of supporting legal and professional infrastructure in East Asian countries (Korea, Malaysia, Thailand) the further reliance and 
advancement of the IFRS did not bring financial stability not only to the region but rather to the global financial system.

For the reason of diverse legal origins, the national enforcement mechanisms, namely regulators, courts, auditors, set a certain direction for the preparers of financial statements. In common law countries (USA, UK, New Zealand) the interests of shareholders are a priority, whereas in civil law countries (Germany, Italy, France) the financial statements are mostly considered of primary interest for banks and tax authorities (Barlev \& Haddad, 2007). The accounting harmonization is not flexible enough to take into account these national peculiarities since the IFRS are obviously geared towards the common law tradition. This raises a rightful question: is the one-size-fits-all accounting solution actually feasible and at what stake?

It could be argued though that the principles-based nature of the IFRS already suggests a built-in flexibility necessary for the application to diverse institutional environments. Some authors even call it a "solution to the problem of accounting harmonization" (Bentson et al., 2006; Carmona \& Trombetta, 2008). However, at the same time, a high degree of discretion provided by generic standards is an impediment to comparability due to subjectivism and variable reporting incentives (Leuz, 2010).

Thus, accounting harmonization is a complex multi-dimensional process which requires an investment of resources and efforts, as well as a certain extent of political interest to enforce it further. Given the diversity of national accounting and legal systems, the complete harmonization is highly unlikely in the nearest future and even undesirable. However at least some degree of convergence seems inevitable due to the continuing processes of globalization. The so-called post-Westphalian world order, or post-national constellation, implies the emergence of a new form of global governance which is necessary in order to align the omnipresent heterogeneity of national legal regimes in the global playfield (Scherer \& Palazzo, 2011). The issue naturally goes beyond the scope of accounting discipline and is equally relevant to the environmental and social concepts. The next section discusses the current situation in sustainability reporting highlighting its benefits and shortcomings, followed by a critical analysis of the desirability of the development of International Financial Reporting Standard on sustainability.

\section{Discussion: Implications for Sustainability Reporting}

The Brundtland Commission (1987) defines sustainability as "development that meets the needs of the present without compromising the ability of future generations to meet their needs". This is the most commonly used definition which, due to its breadth, recognizes the importance of integration of social, economic and environmental issues in the decision-making process (Ermas, 2015). The concept of sustainability emerged in the 1980s and initially was geared towards the environmental aspects; the other components were added at a later stage (Gimenez \& Sierra, 2013). The multi-dimensional nature of sustainability definition implies a response to diverse expectations of a broad group of stakeholders, representing a great opportunity and a serious challenge at the same time.

Besides the fact that there are more than 100 definitions of sustainability (Holmberg \& Sandbrook, 1992), there is also a certain confusion between the terms "corporate social responsibility", "sustainable development" and "corporate sustainability". Whereas the latter two are used interchangeably and are primarily concerned with balance and value (Schwarz \& Caroll, 2008), the former emphasizes the accountability of companies for their activities (Gimenez \& Sierra, 2013).

Sustainable development is closely connected to innovation. Companies contribute to the achievement of sustainable development goals through the generation of new concepts and ideas, implementing innovative approaches and processes. Therefore, from a strategic perspective acting sustainably may bring profit in a form of competitive advantage not easily replicable by other firms (Voegtlin \& Scherer, 2015). Together with the increased competitiveness, innovative practices may lead to improved productivity, whereas the consumers are likely to appreciate company's efforts by higher customer loyalty (Mefford, 2011).

However, this long-term thinking is often not shared due to managers' myopia. Since the investment life-cycle for substantial innovations may be quite long, the benefits may only occur in years. At the same time the research and development costs, as well as the cost of organizational change would be incurred in the short-term. In this regard, the constant pressure to reduce costs and increase profits imposed by investors on companies generates a wide-spread opinion that sustainability is nothing more than a next unnecessary burdensome task.

Nevertheless, in the last decades, many sustainability reporting initiatives have emerged on the global arena. Labeled as the "international accountability standards" (IAS) these voluntary rules attempt to regulate the social and environmental performance of firms (Gilbert \& Rasche, 2008; Rasche, 2009). Recent corporate scandals 
connected with non-compliance of MNCs with ethical and environmental expectations of society underscored the importance of the emergence of such regulations, though not legally binding.

Global Reporting Initiative (GRI) is an example of sustainability reporting standard. GRI, a non-profit organization established in 1997, has developed a framework which includes the guidelines for "triple bottom-line" (economic, environmental and social) reporting (Wilson, 2013). The idea of GRI is to institutionalize sustainability reporting practices in a similar way to financial reporting standards: companies and all other types of organizations voluntarily prepare reports on their sustainability practices in a standard format on a regular basis (Gilbert, Rasche, \& Waddock, 2011; Levy, Brown, \& De Jong, 2009). The usage of a common set of indicators and principles enables benchmarking and comparisons of data between different companies, industries, and geographical regions. Currently, more than 5,000 companies across the globe use GRI standards for their sustainability reporting purposes, which makes them the most widely used sustainability standard in the world (GRI, 2017).

Besides the GRI, there is a great number of other IAS which differ from one another in terms of scope, content, activities involved, target audience and method of application. Such a diversity of standards provides an opportunity for companies to select and apply the standard mostly suited to reflect their economic reality and activities relevant to sustainable development. However, on the other hand, it may create uncertainty about which standard should be used and in what circumstances. Moreover, standards may contain overlapping requirements, which can cause confusion for both, preparers and users. Consequently, the absence of the dominating standard may negatively affect the perception of the IAS legitimacy in general (Gilbert, Rasche, \& Waddock, 2011).

The IAS emerged as a new form of global governance "above and beyond the state" (Scherer \& Palazzo, 2011) due to the decline in regulatory power of national government bodies. In today's globalized world multi-national corporations are able to escape "home" jurisdictions by shifting operations to developing countries where the rule of law may be less apparent. This leads to a highly heterogeneous and imbalanced global legal environment. In this regard, the purpose of the IAS, at the same time representing its major benefit, is to fill in the gaps in global governance and, at least partially, help to align the imbalanced rulemaking.

The significance of IAS development per se should not be underestimated: it draws the attention of society and different stakeholders to environmental and social issues. Harmful practices of MNCs which do not conform to social norms and expectations are criticized, and therefore the underlying legitimacy of their existence is questioned (Scherer \& Palazzo, 2011). These concerns MNCs can no longer ignore. More and more of them incorporate ethical, social and environmental concerns into mission statements and codes of conduct. Many companies voluntarily seek commitments to an increased level of transparency and engage in various kinds of sustainability certification and/or reporting. The preparation of reports involves risk assessments for sustainability activities, elaboration on sustainability strategy and relevant goals. Such company-wide projects enhance the overall understanding of the sustainability concept, in which ways it is applicable to the business and whether it is aligned with the overall strategy and goals of a company. Moreover, some IAS have already turned into industry standards. For example, in global apparel industry being certified in terms of labor conditions is a prerequisite for becoming a supplier (Locke, Amengual, \& Mangla, 2009).

However, some authors argue that the genuine interest of corporations towards sustainability is mainly driven by the public perception of social and environmental issues. Voluntary reporting enhances reputation and company image. The society's pressure can be avoided by following the "green" trend and publishing proper reports, however, in certain cases this may turn out to be nothing more than a greenwash (Mefford, 2011; Wilson, 2013; Banerjee, 2008). Scherer, Palazzo, \& Seidl (2013) consider it a strategic manipulation strategy when a company attempts to create a positive public image which is not substantiated by the appropriate organizational changes. It is a risky strategy, though, as the history knows examples when the uncovered manipulations negatively affected the firm's legitimacy (Pariotta, Gond, \& Schultz, 2011).

The mere existence of such strategy leads to another considerable shortcoming of sustainability reporting, namely the absence of proper steering mechanisms. Without consistent monitoring and enforcement, the impact of IAS is questionable. The costs of organizational change necessary to incorporate sustainability concept into day-to-day business processes are high enough for companies to be tempted by low-hanging fruits of window-dressing. For instance, the case of ENI Corporation is an example of decoupling a company's business operations from the adopted IAS. Recently ENI (2017) published a press-release stating that it is the first Italian company to receive certification in accordance with the requirements of the new ISO 37001: 2016 "Antibribery Management Systems". However, two weeks later the CEO of ENI has been charged with international corruption by Italian prosecutors. 
Such cases foster skepticism about the overall impact of the IAS and their accountability per se. As long as the IAS remain soft law, which, in contrast to hard law, is not legally binding, the compliance with them may appear voluntary and complimentary. This set-up will allow companies to further produce "piecemeal sustainability reports" that contain incomplete or inconsistent data exhibiting the most appealing sides of their business operations (Wilson, 2013). These and other limitations of sustainability reporting discussed in this section represent the main drivers for the introduction of the global standard on sustainability. National enforcement mechanisms limited to the boundaries of home jurisdictions do not suffice for the regulation of sustainable development issues due to their genuinely global scope. By the same token, the existing institutional infrastructure consisting of soft law guidelines cannot adequately address the risks adjacent to innovations. There is a need for an explicit global regulatory framework in order to facilitate responsible innovation (Voegtlin \& Scherer, 2015). In this regard, the convergence between existing IAS should be encouraged (Gilbert, Rasche, \& Waddock, 2011).

At the same time, harmonization for a global standard is a multifaceted process - its necessity and practicality is continually challenged by academics and business practitioners. In the section on accounting harmonization, it has been emphasized that one of the main obstacles to the successful advancement of this process is focused on the differences between countries in terms of culture, legal and tax systems, stakeholders' priority. However, in terms of sustainability concept, this obstacle is even more compelling.

Due to the fact that sustainable development includes social and environmental dimensions, the involvement of local communities in local level reporting is crucial (Lehman, 2005; Gilbert, Rasche, \& Waddock, 2011). Therefore, the reporting should be developed by taking into account local peculiarities, which is not feasible in case of a one-size-fits-all solution. By contrast to the IFRS, sustainability reporting should address the expectations of a far wider range of stakeholders, as well as provide channels for their engagement in sustainability goals formulation. As long as literally any person can be regarded as a stakeholder in this perspective, considerable differences in perceptions are expectable (Willis, 2003). Incorporating these differences is the major challenge of meaningful reporting practice promoting organizational change towards corporate sustainability.

The GRI was initially developed based on the analogy with financial reporting and their similarities were even emphasized. However, such approach was criticized as excessively constraining. It was argued that an analogy to financial reporting would lead to the assurance of minimum compliance, whereas the concept of sustainability implies striving for excellence (Norman \& McDonald, 2004). In this respect, the boundaries created by such a rigid reporting standard might have negated all of its benefits. Consequently, over time the extent of similarity was significantly decreased shifting focus rather to dissimilarities of GRI with financial reporting. This fact corroborates the incompatibility of these two groups of reporting standards justified from a perspective of differences in their rationales: "a compelling business case for the practice" versus "highlighting a broader contribution to society and its long-term interests" (Etzion \& Ferraro, 2010).

\section{Conclusion}

This paper discusses the benefits and drawbacks of the adoption of the IFRS as a single set of accounting standards suited for the needs of the global economy. After exploring the nature and purpose of the international accounting harmonization, I provide a justification why a complete convergence of national accounting standards is unlikely and even undesirable, given the diversity of cultures, enforcement mechanisms, tax and legal systems around the world. The paper then discusses the implications of globalization for reporting on social and environmental issues, providing the analysis of benefits and shortcomings of existing institutional infrastructure for sustainability reporting.

The key message of this paper is the limited applicability of the IFRS paradigm for the purposes of sustainability reporting. By contrast to financial reporting, it is addressed to a much wider group of stakeholders whose engagement is crucial for meaningful sustainable development goals.

This paper clearly demonstrates that further research on the desirability and feasibility of a global robust reporting standard on sustainability is needed to develop the understanding of the drivers in support of the case, as well as the boundaries such a standard may create. The IFRS do not render possible embracing important insights from local communities. This might turn sustainability reporting into "assure minimum compliance" practice not corresponding to the extensive purpose of sustainable development as such.

\section{References}

American Institute of Certified Public Accountants. (2017). International Financial Reporting Standards_Questions and Answers. Retrieved from http://www.ifrs.com/updates/aicpa/ifrs_faq.html\#q5 
Arnold, P. J. (2012). The political economy of financial harmonization: the East Asian financial crisis and the rise of international accounting standards. Accounting, Organizations and Society, 37(6), 361-381. https://doi.org/10.1016/j.aos.2012.05.001

Ball, R. (2006). International Financial Reporting Standards (IFRS): pros and cons for investors. Accounting and Business Research, 36, 5-27. https://doi.org/10.1080/00014788.2006.9730040

Banerjee, S. B. (2008). Corporate social responsibility: the good, the bad and the ugly. Critical Sociology, 34(1), 51-79. https://doi.org/10.1177/0896920507084623

Barlev, B., \& Haddad, J. R. (2007). Harmonization, comparability, and fair value accounting. Journal of Accounting, Auditing \& Finance, 22(3), 493-509.

Benston, G. J., Bromwich, M., Litan, R. E., \& Wagenhofer, A. (2006). Worldwide Financial Reporting: The Development and Future of Accounting Standards. Oxford, UK: Oxford University Press. https://doi.org/10.1093/0195305833.001.0001

Beuselinck, C., Joos, P., Khurana, I., \& Van der Meulen, S. (2009). Mandatory IFRS reporting and stock price informativeness. http://dx.doi.org/10.2139/ssrn.1381242

Brüggemann, U., Daske, H., Homburg, C., \& Pope, P. F. (2009). How do individual investors react to global IFRS adoption? http://dx.doi.org/10.2139/ssrn.1458944

Camfferman, K., \& Zeff, S. A. (2006). Financial Reporting and Global Capital Markets. Oxford, UK: Oxford University Press.

Carlson, P. (1997). Advancing the Harmonisation of International Accounting Standards: Exploring an Alternative Path. The International Journal of Accounting, 32(2), 357-378. https://doi.org/10.1016/S0020-7063(97)90016-9

Carmona, S., \& Trombetta, M. (2008). On the global acceptance of IAS/IFRS accounting standards: The logic and implications of the principles-based system. J. Account. Public Policy, 27, 455-461. https://doi.org/10.1016/j.jaccpubpol.2008.09.003

Corporate Responsibility Magazine. (2016). Opinion: GRI—The Enemy Of Good Reporting? Retrieved from $\mathrm{http} / / / \mathrm{www}$.thecro.com/topics/reporting/opinion-gri-the-enemy-of-good-reporting/

Costa, M., \& Guzzo, G. (2013). Fair Value Accounting versus Historical Cost Accounting: a theoretical Framework for judgment in financial crises. Corporate Ownership \& Control, 11(1), 146-152. https://doi.org/10.22495/cocv11i1conf2p6

Daske, H., Hail, L., Leuz, C., \& Verdi, R. S. (2008). Mandatory IFRS reporting around the world: Early evidence on the economic consequences. Journal of Accounting Research, 46(5), 1085-1142. https://doi.org/10.1111/j.1475-679x.2008.00306.x

Daske, H., Hail, L., Leuz, C., \& Verdi, R. S. (2011). Adopting a Label: Heterogeneity in the economic consequences of IFRS adoptions.

De George, E. T. (2013). Consequences of Accounting Harmonization: IFRS adoption and Cross-Border Contagion. Diss. University of Michigan.

DeFond, M., Hu, X., Hung, M., \& Li, S. (2011). The impact of mandatory IFRS adoption on foreign mutual fund ownership: The role of comparability. Journal of Accounting and Economics, 51(3), 240-258. https://doi.org/10.1016/j.jacceco.2011.02.001

Deloitte Touche Tohmatsu. (2017). IASB Conceptual Framework. Retrieved from https://www.iasplus.com/en/standards/other/framework

Diaconu, P. (2007). Impact of Globalization on International Accounting Harmonization. SSRN Electronic Journal. http://dx.doi.org/10.2139/ssrn.958478

Dowling, G. R. (2014). The curious case of corporate tax avoidance: is it socially irresponsible? Journal of Business Ethics, 124(1), 173-184. https://doi.org/10.1007/s10551-013-1862-4

Eni. (2017). Press release: Eni becomes the first Italian company to obtain the ISO 37001:2016 "Antibribery Management Systems" certificate of conformity for its Anti-Corruption Compliance Program. Retrieved from

https://www.eni.com/en_IT/media/2017/01/eni-becomes-the-first-italian-company-to-obtain-the-iso-370012 016-antibribery-management-systems-certificate-of-conformity-for-its-anti-corruption-compliance-program 
Ermas, R. (2015). The Concept of Sustainable Development: Definition and Defining Principles. Retrieved from https://sustainabledevelopment.un.org/content/documents/5839GSDR\%202015_SD_concept_definiton_rev. pdf

Etzion, D., \& Ferraro, F. (2010). The Role of Analogy in the Institutionalization of Sustainability Reporting. Organization Science, 21(5), 1092-1107. https://doi.org/10.1287/orsc.1090.0494

European Commission. (2009). Leader's Statement: The Pittsburgh Summit (September 24-25, 2009). Retrieved from http://ec.europa.eu/archives/commission_2010-2014/president/pdf/statement_20090826_en_2.pdf

Financial Times. (2017). Eni chief Claudio Descalzi charged with international corruption 08/02/2017. Retrieved from https://www.ft.com/content/87983836-ee13-11e6-930f-061b01e23655

Florou, A., \& Pope, P. F. (2012). Mandatory IFRS adoption and investor asset allocation decisions. The Accounting Review, 87(6), 1993-2025. https://doi.org/10.2308/accr-50225

Francis, J., Huang, S., \& Khurana, I. (2012). The role of international GAAP in cross-border mergers and acquisitions. Working paper, University of Arkansas. http://dx.doi.org/10.2139/ssrn.2131472

Gilbert, D. U., \& Rasche, A. (2008). Opportunities and problems of standardized ethics initiatives: A stakeholder theory perspective. Journal of Business Ethics, 82, 755-773. https://doi.org/10.1007/s10551-007-9591-1

Gilbert, D. U., Rasche, A., \& Waddock, S. (2011). Accountability in a global economy: the emergence of international accountability standards. Business Ethics Quarterly, 21(1), 23-44. https://doi.org/10.5840/beq20112112

Gimenez, C., \& Sierra, V. (2013). Sustainable supply chains: governance mechanisms to greening suppliers. Journal of Business Ethics, 116(1), 189-203. https://doi.org/10.1007/s10551-012-1458-4

Global Reporting Initiative. (2017). An introduction to G4. Retrieved from https://www.globalreporting.org/resourcelibrary/GRI-An-introduction-to-G4.pdf

Goeltz, R. K. (1991). International Accounting Harmonisation: The Impossible (and Unnecessary?) Dream. Accounting Horizons, 5(1), 85-89.

Holmberg, J., \& Sandbrook, R. (1992). Sustainable Development: What is to be Done? In J. Holmberg (Ed.), Policies for a Small Planet (pp. 19-38). London: Earthscan.

Horton, J., Serafeim, G., \& Serafeim, I. (2013). Does mandatory IFRS adoption improve the information $\begin{array}{llll}\text { environment? } \quad \text { Contemporary Accounting } & \text { Research, }\end{array}$ https://doi.org/10.1111/j.1911-3846.2012.01159.x

Johnson, G., Scholes, K., \& Whittington, R. (2008). Exploring corporate strategy: text \& cases. Essex: Pearson Education.

Lehman, G. (2005). A critical perspective on the harmonization of accounting in a globalizing world. Critical Perspectives on Accounting, 16(7), 975-992. http://doi.org/10.1016/j.cpa.2003.06.004

Leuz, C. (2010). Different approaches to corporate reporting regulation: how jurisdictions differ and why. Accounting and Business Research, 40(3), 229-256. https://doi.org/10.1080/00014788.2010.9663398

Levy, D. L., Brown, H. S., \& De Jong, M. (2009). The contested politics of corporate governance: The case of the Global Reporting Initiative. Business \& Society, 49, 88-115. https://doi.org/10.1177/0007650309345420

Li, S. (2010). Does mandatory adoption of International Financial Reporting Standards in the European Union reduce the cost of equity capital? The Accounting Review, 85(2), 607-636. http://dx.doi.org/10.2308/accr.2010.85.2.607

Locke, R., Amengual, M., \& Mangla, A. (2009). Virtue out of necessity? Compliance, commitment and the improvement of labor conditions in global supply chains. Politics and Society, 37, 319-351. https://doi.org/10.1177/0032329209338922

Mackenzie, B. (2013). Interpretation and application of International Financial Reporting Standards 2013. Hoboken (N. J.): J. Wiley.

Mefford, R. (2011). The Economic Value of a Sustainable Supply Chain. Business and Society Review, 116(1), 109-143. https://doi.org/10.1111/j.1467-8594.2011.00379.x

Norman, W., \& MacDonald, C. (2004). Getting to the bottom of "triple bottom line." Bus. Ethics Quart., 14(2), 243-262. https://doi.org/10.5840/beq200414211 
Palea, V. (2007). The effects of the IAS/IFRS adoption in the European Union on the financial industry. The European Union Review, 12(1-2). http://doi.org/10.1016/j.cjar.2013.08.003

Patriotta, G., Gond, J., \& Schultz, F. (2011). Maintaining legitimacy: controversies, orders of worth, and public $\begin{array}{lllll}\text { justifications. Journal of Management } & \text { Studies, } & \text { 48, } & \text { 1804-1836. }\end{array}$ http://dx.doi.org/10.1111/j.1467-6486.2010.00990.x

Phan, D., Mascitelli, B., \& Barut, M. (2013). Perceptions of Accounting Professionals towards International Financial Reporting Standards (IFRS) in Developing Country: Evidence from Vietnam. Rydges Melbourne: The 3rd Global Accounting, Finance, and Economics Conference.

Ramanna, K., \& Sletten, E. (2009). Why do countries adopt International Financial Reporting Standards? Harvard Business School. Retrieved from http://www.hbs.edu/faculty/Publication\%20Files/09-102.pdf

Rasche, A. (2009). "A necessary supplement": What the United Nations Global Compact is and is not. Business and Society, 48, 511-537. https://doi.org/10.1177/0007650309332378

Scherer, A. G., \& Palazzo, G. (2011). The new political role of business in a globalized world: a review of a new perspective on CSR and its implications for the firm, governance, and democracy. Journal of Management Studies, 48(4), 899-931. https://doi.org/10.1111/j.1467-6486.2010.00950.x

Scherer, A. G., Palazzo, G., \& Seidl, D. (2013). Managing legitimacy in complex and heterogeneous environments: sustainable development in a globalized world. Journal of Management Studies, 50(2), 259-284.

Schwartz, M. S., \& Carroll, A. B. (2008). Integrating and unifying competing and complementary frameworks. Business \& Society, 47(2), 148-186. https://doi.org/10.1177/0007650306297942

Sikka, P. (2010). Smoke and mirrors: corporate social responsibility and tax avoidance. Accounting Forum, 34(3), 153-168. https://doi.org/10.1016/j.accfor.2010.05.002

Tarca, A. (2012). The case for global accounting standards: arguments and evidence. Retrieved from https://papers.ssrn.com/sol3/papers2.cfm?abstract_id=2204889

Taylor, S. L. (1987). International Accounting Standards: An Alternative Rationale. Abacus, 23(2), 157-171. https://doi.org/10.1111/j.1467-6281.1987.tb00147.x

Turner, J. (1983). International harmonization: a professional goal. The advantages of and barriers to a universally applicable system of accounting principles. Journal of Accountancy, 155(1), 58-66.

Tweedie, D., \& Seidenstein, T. R. (2004). Setting a global standard: the case for accounting convergence. Northwestern Journal of International Law and Business, 25(3), 589.

Voegtlin, C., \& Scherer, A. G. (2015). Responsible innovation and the innovation of responsibility: governing sustainable development in a globalized world. Journal of Business Ethics, 1-17. https://doi.org/10.1007/s10551-015-2769-z

Walker, M. (2010). Accounting for varieties of capitalism: The case against a single set of global accounting standards. British Accounting Review, 42(3), 137-152. http://doi.org/10.1016/j.bar.2010.04.003

Wang, C. (2014). Accounting Standards Harmonization and Financial Statement Comparability: Evidence from Transnational Information Transfer. Journal of Accounting Research, 52(4), 955-992. https://doi.org/10.1111/1475-679X.12055

Whittington, G. (2008). Harmonisation or discord? The critical role of the IASB conceptual framework review. Journal of Accounting and Public Policy, 27(6), 495-502. http://doi.org/10.1016/j.jaccpubpol.2008.09.006

Willis, A. (2003). The Role of the Global Reporting Initiative's Sustainability Reporting Guidelines in the Social Screening of Investments. Journal of Business Ethics, 43(3), 233. https://doi.org/10.1023/A:1022958618391

Wilson, M. C. (2015). A critical Review of Environmental Sustainability Reporting in the Consumer Goods Industry: Greenwashing or Good Business? Journal of Management and Sustainability, 3(4), 1. http://dx.doi.org/10.5539/jms.v3n4p1

Yu, G. (2009). Accounting standards and international portfolio holdings: Analysis of cross-border holdings following mandatory adoption of IFRS. http://dx.doi.org/10.2308/accr-50801

Zeff, S. A. (2007). Some obstacles to global financial reporting comparability and convergence at a high level of quality. The British Accounting Review, 39(4), 290-302. https://doi.org/10.1016/j.bar.2007.08.001 
Zeff, S. A. (2012). The evolution of the IASC into the IASB, and the challenges it faces. The Accounting Review, $87(3), 807-837$.

\section{Copyrights}

Copyright for this article is retained by the author(s), with first publication rights granted to the journal.

This is an open-access article distributed under the terms and conditions of the Creative Commons Attribution license (http://creativecommons.org/licenses/by/4.0/). 